\title{
Eugenic Thinking
}

\author{
Robert A. Wilson*
}

\begin{abstract}
The Eugenic Mind Project explores and critiques both past and present eugenic thinking. Informed by the perspectives of Canadian eugenics survivors in the province of Alberta and standpoint theory, The Eugenic Mind Project draws on both my intimate acquaintance with eugenics in Canada and my previous thinking about the cognitive, biological, and social sciences, the fragile sciences. It recounts the history of eugenics and the thinking that drove it, and critically engages contemporary manifestations of eugenic thought, newgenics. Accessible to philosophers of the biological and social sciences, historians of science and medicine, bioethicists, and those working on race, disability, or gender, the book aims to enrich ongoing discussions about human nature and human diversity, the social uses of biotechnology, and social policies governing future generations.
\end{abstract}

\section{Keywords \\ disability $\bullet$ eugenics $\bullet$ human diversity $\bullet$ human kinds $\bullet$ human nature $\bullet$ immigration restriction $\bullet$ newgenics $\bullet$ prenatal screening $\bullet$ sterilization $\bullet$ standpoint theory \\ Part of an author-meets-critics book symposium on The Eugenic Mind Project by Robert A. Wilson (MIT Press, 2018) with Kendig 2018 and Love 2018.}

Projects of human improvement take both individual and intergenerational forms. The biosciences provide many technologies, including prenatal screening and the latest gene editing techniques, such as CRISPR, that have been viewed as providing the means to human improvement across generations. But who is fit to furnish the next generation? Historically, eugenics epitomizes the science-based attempt to improve human society through distinguishing kinds of people and then implementing social policies - from immigration restriction to sexual sterilization and euthanasia - that influence and even direct what sorts of people populate our future. Despite recognition of the horrors of the eugenic extremes of the past and of the subhumanizing of those sufficiently below appearance or ability norms to be viewed as "defective" or "unfit", many people continue to be drawn to strands of eugenic thinking.

The Eugenic Mind Project is a wide-ranging, philosophical book that explores and critiques both past and present eugenic thinking. It draws on my intimate acquaintance with eugenics

*Department of Politics and Philosophy, La Trobe University, Melbourne Victoria 3086, Australia rwilson.robert@gmail.com

Received 24 June 2018; Accepted 19 July 2018 doi:10.3998/ptpbio.16039257.0010.012

○ OPEN ACCESS - PTPBIO.ORG 
in North America, a familiarity generated by working closely over an extended period of time with survivors of eugenics in the Canadian province of Alberta. That work began shortly after I moved to the University of Alberta from the University of Illinois, Urbana-Champaign in 2000. In teaching a few standard weeks on eugenics that focused on Nazi and American eugenics, just as I had in my "Biology and Society" course at Illinois, at Alberta I found myself educated by students who knew something about eugenics that I didn't. They had such knowledge not because of some previous, special course of study but because some of their living relatives had been sterilized under the auspices of The Sexual Sterilization Act of Alberta, a provincial law in place from 1928 until 1972. While their knowledge as young adults here was not first- but second-hand, it soon led me to meet people even more closely connected to what I thought of as the eugenic past, people who had been institutionalized and sterilized putatively in accord with The Sexual Sterilization Act. Revelations about the university (indeed, department) that I had just joined as a professor of philosophy also brought eugenics closer to home.

Over time, a small number of those who had lived through a eugenic past became my friends. Although the book occasionally draws on ideas - such as the leading idea in Chapter 8-that emerged from our pairwise and small group conversations and other interactions- the influence of these friendships on my thinking about eugenics has been more pervasive than this may suggest. A recent essay in Aeon, "Eugenics never went away", that I had originally entitled "The feeling of eugenics", gives perhaps the clearest sense of how my experiences while at Alberta have shaped the approach to eugenics taken in the book.

The Eugenic Mind Project draws on my previous work on the cognitive, biological, and social sciences, the fragile sciences, particularly in my Boundaries of the Mind and Genes and the Agents of Life. It identifies eugenics itself amongst the fragile sciences at the interface of late nineteenth-century ideas about the mind, biology, and sociality, recounts the history of eugenics and the thinking that drove it, explores the roots of eugenic thinking, and critically engages contemporary manifestations of eugenic thought, newgenics. And like much of the burgeoning scholarship on eugenics, it aims to provoke and enrich discussions about human nature and human diversity, about the social uses of biotechnology, and about social policies governing future generations.

Anything more than passing knowledge of the history of eugenics between 1865 and 1945 typically leads those engaged in reflection on the contemporary biosciences to raise questions about the potential misuse of emerging ventures in biotechnology. That reflection casts at least a shadow of caution over future uses of existing reproductive technologies to create so-called designer babies and to discard embryos or fetuses that do not measure up to either ideals or norms. Contemporary philosophers and bioethicists have sometimes seen their role in terms of escaping from that shadow in sorting the wheat from the chaff of eugenics, using their conceptual acumen to identify defensible forms of, or aspects to, eugenics.

A shadow of caution certainly pervades the general scholarship on eugenics and can be found in the earliest and most influential work on the history of eugenics. In his preface to the second edition of In the Name of Eugenics, the historian Daniel Kevles cautioned that the "specter of eugenics hovers over virtually all contemporary developments in human genetics" (1995, ix). And the sociologist Troy Duster's Backdoor to Eugenics likewise presciently warned of eugenic futures being created by the backdoor of individual choice. For both Kevles and Duster, the dangers of dormant eugenic ideas remain nascent in present and emerging biotechnologies. The message here has been clear: understand past eugenics, critique present eugenics, avoid future eugenics.

Despite that message, there remains a feeling of distance between ourselves and the eugenic past to which, I believe, our collective scholarship has inadvertently contributed. In my view, 
this is in part because that scholarship has developed largely without attention to the perspective of eugenics survivors themselves. By adopting what I call a standpoint eugenics-eugenics from the standpoint of those who have survived and those who continue to survive eugenics past and present-The Eugenic Mind Project attempts to dispel whatever lingering feelings of distance from a eugenic past remain. From that standpoint, the pro-eugenic, arm's-length bravado shown particularly by philosophers and bioethicists in sorting the wheat from the chaff in eugenics past, present, and future have a different feel to them.

I have already signalled that, in my own case, that feeling of distance dissolved through my personal connections with Alberta students and survivors of eugenics for whom eugenics was not at arm's length at all. But eugenics came closer to home in another way due to peculiarities of the history of the Department of Philosophy at the University of Alberta. While there were a number of students in my class who had relatives who had been sterilized on eugenic grounds, many more were familiar with the history of eugenics in the province because in the immediately preceding years-roughly 1995 until 2000-over 900 cases for wrongful confinement and sterilization had been filed against the Province of Alberta, the vast majority of which had been eventually settled by the government of then premier Ralph Klein. These actions followed the successful lawsuit of a very brave and persistent woman, Leilani Muir, with whom I became particularly close friends. In the course of both Leilani's case and those settled in light of it, the activity of Alberta's "Eugenics Board" came under critical scrutiny, much of which was widely reported in popular media venues. That board was headed for most of its history-right through until 1965-by the founding chair of Philosophy at the University of Alberta, John MacEachran, who is also the university's longest-serving Provost.

The introductory chapter, "Standpointing Eugenics", locates and explains my personal and professional interests in eugenics and expands upon these remarks. It says a little more about Alberta's eugenic past, briefly describes the five-year, federally-funded project-the Living Archives on Eugenics in Western Canada project - that brought together eugenics survivors, students, researchers, and community leaders to engage around the topic of eugenics, and attempts to be more explicit about the impact of working directly with eugenics survivors. Identifying what I call institutional complicity and engaged individuality as two dimensions anchoring the ensuing discussion in the book, the chapter concludes by discussing recent cases of the sterilization of women and girls with intellectual disabilities in Australia in 2012, Latina and African-American women in the California prison system in 2013, and low-caste women in India in 2014. The chapter as a whole raises questions about the relationships between eugenics past and present. To take one posed and discussed in some of the recent historiography (e.g., Levine and Bashford 2010; Paul 2016; Reilly 2015), casting it here in my own terms: how does eugenic thinking, The Eugenic Mind, continue on beyond the 80-year social movement, ending in 1945, that was eugenics? And to take one that is perhaps original to the book and central to the chapters in Part Two of it: where does The Eugenic Mind come from?

This introductory chapter is the first of four chapters in Part One that focus on particular activities central to my perspective on eugenics: standpointing, characterizing, specifying, and subhumanizing. Drawing on Francis Galton's early characterization of eugenics to offer a working characterization of eugenics useful for understanding eugenic thinking more generally, the second chapter, "Characterizing Eugenics", positions eugenics as an applied science and a social movement and identifies the importance to The Eugenic Mind of the idea of sorts of people. The chapter discusses the place of race, ethnicity, and disability in the practices of The Eugenic Mind, identifying feeblemindedness or mental deficiency as a central eugenic trait. Although the chapter covers much ground that is well-trodden by historians of eugenics, the focus on the kind of thinking that permeates eugenics distinguishes the perspective that emerges. Con- 
centrating on what I call the short history of eugenics from 1865 to 1945 , the chapter also reaches back to interrogate the claim that eugenics also has a long past and suggests an intimate connection between eugenics past and present thinking.

What were the traits that some people had that made them targets of eugenics in the past? We can answer this question by exploring research publications, popular culture, and marriage and immigration laws. But the most powerful way to determine what a eugenic trait is involves examining eugenic sexual sterilization legislation. The third chapter, "Specifying Eugenic Traits", contains a synoptic view of all such legislation passed in North America in the twentieth century across thirty-five jurisdictions. By comparing the province of Alberta's sexual sterilization law and its implementation to American eugenic laws, the chapter shows the role that institutionalization played in the social mechanics of eugenics and underscores the centrality of mental health to The Eugenic Mind. It concludes by drawing out some general conclusions about three eugenic traits and their atypical presence in Canadian eugenics: syphilis, Huntington's, and epilepsy.

Chapter 4, "Subhumanizing the Defective", takes up themes of life worthiness and subhumanization in The Eugenic Mind. The question "what sorts of people should there be?" remains live for philosophers and bioethicists who have reopened consideration of eugenics under headings such as "liberal eugenics" or "procreative beneficence". Yet that consideration typically neglects the significance of the subhumanization of the targets of eugenics in the short history of eugenics. Within standpoint eugenics, subhumanization looms large in continuing discussions, particularly by philosophers and bioethicists, of the differential life worthiness of different sorts of people. Discussing the relationship between eugenics and euthanasia and the forms that subhumanization took in Alberta's eugenic past, as well as recent challenges that cognitive disability has posed to philosophical ethics in discussions of newgenics, the chapter illustrates standpoint eugenics in action. It concludes with reflection on a recent, widely discussed case involving intellectual disability, that of the child known in both the academic literature and social media as "Ashley X".

The next four chapters constitute Part Two of the book and focus on understanding the persistence of eugenics and what I call its social mechanics. The fifth chapter, "Where Do Ideas of Human Variation Come From?", begins by returning to consider the prosociality that motivates eugenic interventions and its relationship to views of human diversity and variation. It articulates a novel problem, what I call the puzzle of marked variation, and outlines four initial desiderata that a response to the puzzle should meet. The puzzle of marked variation is quite general and can be raised with respect to many ways of sorting people, but this chapter focuses on its application to categories of disablement and their relationship to sub-normalcy. The chapter argues that the appeal to biopolitics and the socially constructed nature of disability offered by those drawing on the work on Michel Foucault - such as Lennard Davis, Nikolas Rose, and Shelley Tremain-are more limited than is suggested by their popularity in explorations of the relationship between disability and eugenics. The chapter concludes by drawing on a variant of the open question argument against naturalism in ethics that traces back to the philosopher G. E. Moore to extend the list of desiderata for responses to the puzzle of marked variation.

The desiderata introduced in Chapter 5 not only help to identify problems with the appeal to biopolitics in discussions of eugenics and disability but also suggest that the puzzle of marked variation has both psychological and social dimensions. Beginning with a point about human vulnerability that can be traced to the work of the political philosopher Thomas Hobbes and drawing on my past and ongoing work on situated cognition and collective intentionality, Chapter 6, "A Socio-Cognitive Framework for the Puzzle of Marked Variation", introduces 
a general framework for addressing the puzzle of marked variation that straddles the fragile sciences of cognition and sociality. It discusses what is distinctive about human sociality and prosociality and identifies the cognitive demands that each makes. As a species, we have developed distinctive forms of cognition that are situated, extended, and collective and which are integral to our prosociality. The resulting cognitively-mediated normativity we possess allows us to distinguish between sorts of people. That, in turn, creates the possibility of treating those who are perceived or thought of as being like us - as being of our kind-differently than we treat others. In postulating a "like us" detector and clarifying the idea of first-person, plural mechanisms, the chapter specifies the nature of some of the socio-cognitive mechanisms hypothesized as being operant in The Eugenic Mind.

Chapter 7, "Backdoors, Newgenics, and Eugenics Underground", returns to consider in more detail appeals to newgenics, the so-called backdoor to eugenics, and issues arising at the interface of contemporary bioethics and disability. Working with the disability theorist Rosemarie Garland-Thomson's idea of a eugenic logic, the chapter recasts the debate over the disability rights critique of prenatal screening with selective abortion and identifies newgenic strains in contemporary bioethical thinking about procreation. My aim with respect to the first of these has been to keep the focus squarely on selective abortion and disability without entering larger debates over, or the history of, reproductive rights and abortion (cf. Dyck 2013, chap. 7-8). The discussion of selective abortion and disability here shares with the original disability rights critiques offered by Adrienne Asch and Marsha Saxton the assumption that abortion is in general permissible. Yet like those critiques, my discussion also shares the permanent possibility of being appropriated by "pro-life" factions in debates over abortion, possibilities heightened in present US politics. The application of the principle of procreative beneficence, articulated and defended by the philosopher Julian Savulescu to argue that reproduction should be free of disability, is rejected and the general character of eugenics under neoliberalism identified and critically discussed. The chapter, which draws in part on joint work with Matthew Barker and Joshua St. Pierre, concludes with a discussion of eugenic silencing by focusing on autism and self-advocacy.

The eighth chapter, "Eugenics as Wrongful Accusation", completes the exploration of the persistence of eugenics by introducing another dimension to the social mechanics of eugenics. It begins with a question about eugenics after 1945: how is it that eugenic practices, such as sterilization, didn't simply disappear or cease? In offering an answer to this question, the chapter further develops the socio-cognitive framework, working very much across the borders that are usually drawn between the social and the psychological and further documenting the corresponding continuities between eugenics past and newgenics present. The subject matter here is not the origins of our ideas of human variation, as in Chapters 5 and 6, nor their manifestation in contemporary newgenics and the continuity between eugenics and newgenics, as in Chapter 7; rather, it is the persistence of old-fashioned eugenics itself.

The novel perspective that the chapter introduces is to view eugenics as wrongful accusation, a phenomenon best understood through a paradigm example: the ritual sexual abuse cases predominant in the 1980s and 1990s. The explanatory value of this assimilation of eugenics to such cases lies in what it reveals about the psycho-social dynamics of eugenics. Here the chapter draws on the work of Judith Herman on trauma and witnessing, though it takes those ideas in a direction that Herman herself (and those whom she has influenced in thinking about witnessing and sex crimes) would likely resist.

Having introduced the idea of standpoint eugenics early in Chapter 1, the book has proceeded by approaching The Eugenic Mind from the perspectives of eugenics survivors. In the final two chapters, which make up Part Three, the discussion returns to reflect more explicitly 
on the nature of standpoint eugenics itself. Chapter 9, "Knowing Agency", develops the idea of what I call knowing agency at the margins by drawing on standpoint theory in epistemology, with particular attention given to the standing and credibility of cognitive disability in philosophy. There is a kind of unacknowledged epistemic apartheid in approaches to the general idea that knowledge is contextual that itself shapes how marginal knowers are viewed in the discipline of philosophy. The politics of epistemic apartheid-between feminism and analytic epistemology, for example-forms part of the context in which the possibilities for standpoint eugenics can be envisaged and assessed. What it's like to occupy the marginalized standpoint of cognitive disability is conveyed through a discussion of the work and perspective of Eva Kittay.

The final chapter, "Standpoint Eugenics Unbound: Survivorship for the Subhuman", articulates and takes up some of the internal complexities to applying standpoint theory to eugenics and disability. Standpoint theory applies paradigmatically to class and gender, and has been deployed with respect to other examples, such as race and sexuality within feminist standpoint theory. The generalization of standpoint theory to disability, particularly intellectual disability, faces distinctive problems that derive from the focus of standpoint theory on class and gender and the kind of view of the dynamics of knowing agency from the margins that holds in these cases. Here I make use of the ideas of joint action and extended action familiar from the cognitive sciences, and, taking my cue from work in the philosophy of biology, raise questions about the significance for standpoint eugenics of the intrinsic heterogeneity of categories of disablement. Whether there are the sorts of people posited in The Eugenic Mind is an issue that also affects the prospects for a robust standpoint eugenics. Perhaps we will need to be satisfied, after all, with a standpoint-ish eugenics, a perspective on eugenics that takes seriously the motivations for and orientation of standpoint theory but which stops short of applying an adapted form of standpoint theory to eugenics and disability.

\section{Acknowledgments}

I want to thank the participants in this multiauthor review for their probing of some of the ideas in The Eugenic Mind Project, both here (Love 2018; Kendig 2018) and in the author-meets-critics symposium they participated in at ISHPSSB 2017 in São Paolo, Brazil. I would also like to thank the journal and its editors for their enthusiasm about the format and topic, and an anonymous reviewer for helpful feedback. I would also like to acknowledge the financial support of the Social Sciences and Humanities Research Council of Canada for the Living Archives on Eugenics in Western Canada project (2010-2016).

\section{Literature cited}

Agar, Nicholas. 2004. Liberal Eugenics: In Defence of Human Enhancement. Malden, MA: Blackwell.

Asch, Adrienne. 1989. "Reproductive Technology and Disability". In Reproductive Laws for the 1990s, edited by Sherrill Cohen and Nadine Taub, 69-124. Clifton, NJ: Humana Press.

Asch, Adrienne. 2003. "Disability Equality and Prenatal Testing: Contradictory or Compatible?" Florida State University Law Review 30 (2): 315-342.

Davis, Lennard. 1995. Enforcing Normalcy: Deafness, Disability and the Body. London: Verso.

Duster, Troy. (1990) 2003. Backdoor to Eugenics. New York: Routledge.

Dyck, Erika. 2013. Facing Eugenics: Reproduction, Sterilization, and the Politics of Choice. Toronto: University of Toronto Press.

๑ OPEN ACCESS - PTPBIO.ORG 
Garland-Thomson, Rosemarie. 2012. “The Case for Conserving Disability.” Journal of Bioethical Inquiry 9 (3): 339-55.

Herman, Judith Lewis. (1992) 1997. Trauma and Recovery. New York: Basic Books.

Kendig, Catherine. 2018. "Considering the Role Marked Variation Plays in Classifying Humans: A Normative Approach”. Philosophy, Theory, and Practice in Biology 10 (13). http://dx.doi.org/10. 3998/ptpbio.16039257.0010.013.

Kevles, Daniel. (1985) 1995. In the Name of Eugenics. Cambridge, MA: Harvard University Press.

Kittay, Eva Feder. 2009. "The Personal is Philosophical is Political: A Philosopher and Mother of a Cognitively Disabled Person Sends Notes from the Battlefield.” Metaphilosophy 40 (3-4): 606627. Also reprinted in Cognitive Disability and its Challenge to Moral Philosophy, edited by Eva Feder Kittay and Licia Carlson, 393-413. New York: Wiley-Backwell.

Kittay, Eva Feder. 2017. “The Moral Significance of Being Human”. Proceedings and Addresses of the American Pbilosophical Association 91: 22-42.

Levine, Philippa, and Alison Bashford. 2010. "Introduction: Eugenics and the Modern World". In The Oxford Handbook of the History of Eugenics, edited by Alison Bashford and Philippa Levine, 3-24. New York: Oxford University Press.

Love, Alan C. 2018. "Philosophy in the Trenches: Reflections on The Eugenic Mind Project". Philosophy, Theory, and Practice in Biology 10 (14). http://dx.doi.org/10.3998/ptpbio.16039257.0010. 014.

Muir, Leilani. 2014. A Whisper Past: Childless after Eugenic Sterilization in Alberta. Victoria, BC: Friesen Press.

Paul, Diane. 2016. "Reflections on the Historiography of American Eugenics: Trends, Fractures, Tensions". Journal of the History of Biology 49: 641-58.

Reilly, Philip R. 2015. “Eugenics and Involuntary Sterilization: 1907-2015”. Annual Review of Genomics and Human Genetics 16: 351-368.

Rose, Nikolas. 1985. The Psychological Complex: Psychology, Politics and Society in England 1969-1939. London: Routledge and Kegan Paul.

Savulescu, Julian. 2001. "Procreative Beneficence: Why We Should Select the Best Children”. Bioethics 15 (5/6): 413-426.

Saxton, Marsha. 1984. "Born and Unborn: The Implications of Reproductive Technologies for People with Disabilities". In Test-Tube Women: What Future for Motherhood, edited by Rita Arditti, Renate Duelli Klein, and Shelley Minden, 298-312. London: Pandora Press.

Saxton, Marsha. 1997. "Disability Rights and Selective Abortion”. In Abortion Wars: A Half Century of Struggle, 1950-2000, edited by Rickie Solinger, 374-395. Berkeley, CA: University of California Press.

Tremain, Shelley. 2001. "On the Government of Disability." Social Theory and Practice 27 (4): 617636.

Wilson, Robert A. 2004. Boundaries of the Mind: The Individual in the Fragile Sciences: Cognition. New York: Cambridge University Press.

Wilson, Robert A. 2005. Genes and the Agents of Life: The Individual in the Fragile Sciences: Biology. New York: Cambridge University Press.

Wilson, Robert A. 2015. "The Role of Oral History in Surviving a Eugenic Past". In Beyond Testimony and Trauma: Oral History in the Aftermath of Mass Violence, edited by Steven High, 119-138. Vancouver, BC: University of British Columbia Press. 
Wilson, Robert A. 2017a. "Collective Intentionality in Non-human Animals". In Routledge Handbook on Collective Intentionality, edited by Marija Jankovic and Kirk Ludwig, 420-432. New York: Routledge.

Wilson, Robert A. 2017b. "Group-level Cognizing, Collaborative Remembering, and Individuals”. In Collaborative Remembering: Theories, Research, and Applications, edited by Michelle Meade, Penny Van Bergen, Celia Harris, John Sutton, and Amanda Barnier, 248-260. Oxford: Oxford University Press.

Wilson, Robert A. 2018, “Eugenics Never Went Away.” Aeon Magazine, June 5, 2018. https://aeon.co/ essays/eugenics-today-where-eugenic-sterilisation-continues-now.

Wilson, Robert A., and Matthew J. Barker. 2018. "Well-Being, Disability, and Choosing Children". Mind fzy039. https://doi.org/10.1093/mind/tzy039.

Wilson, Robert A., and Joshua St. Pierre. 2016. "Eugenics and Disability”. In Retbinking Disability: World Perspectives in Culture and Society, edited by Patrick Devlieger, Beatriz Miranda-Galarza, Steven E. Brown, and Megan Strickfaden, 93-112. Antwerp: Garant Publishing.

(C) 2018 Author(s)

This is an open-access article distributed under the terms of the Creative Commons Attribution 4.0 International license, which permits anyone to download, copy, distribute, or display the full text without asking for permission, provided that the creator(s) are given full credit.

ISSN 2475-3025 